\title{
The Transformation of the Teaching Mode of German Course Based on Corpus - Taking the Sino-German Joint Education Cooperation in Qilu University of Technology (SDAS) as an Example
}

\section{Fei Sun}

School of Foreign Languages, Qilu University of Technology (Shandong Academy of Sciences), Jinan 250353, Shandong, China Email: 15195860908@163.com

Abstract: Taking the Sino-German cooperative education project in mechanical and automotive engineering major of Qilu University of Technology (SDAS) for example, this paper mainly introduces the changes of teaching mode of German courses based on the corpus. The transformation of the teaching mode consists of both teaching methods and teaching contents. The teaching method has changed from teacher-teaching method to a hybrid method of "student self-exploration + group discussion + teacher guidance", and the teaching content has changed from "German" learning to "German +" learning. Changes above are shown and supported by project curriculum examples, which in turn demonstrate the role of corpus in foreign language teaching.

Keywords: corpus, German course, transformation of the teaching mode

\section{Introduction}

The cooperation project between the Qilu University of Technology (SDAS) and the North Hesse University of Applied Sciences is an undergraduate education project in mechanical design and manufacturing and automation (Sino-German cooperation) major approved by the Ministry of Education of the People's Republic of China. The German course system in this project is divided into German language courses and German professional (mechanical) courses. The first academic year focuses on German language training, and the German professional (mechanical) courses taught by German teachers start from the second semester of the second academic year.

The German professional (mechanical) teaching stage requires high language proficiency and strong professionalism for students. However, a large number of investigations have indicated that excessive specialization of vocabulary and sentence patterns hinder students' understanding of the content. Research have also showed that most of the mechanical vocabulary relates to commonly used vocabulary. For example, "die Mutter" which means "mother" in daily life, has the meaning "nut" in the mechanical field It is obvious that the teaching of professional vocabulary and sentence patterns integrated into the basic language learning stage is of great benefit to the later professional learning.

\section{The integration of corpus and teaching modes}

Since Tim Johns (1991) proposed the data-driven learning method, the use of corpus for foreign language teaching has become an important method of modern foreign language teaching. This method conforms with the learning concept of constructivism, emphasizing on "learning by doing" of the students. The corpus, as a text base with a large number of language facts, can provide a basic contextual environment for language learning. Even for science students who have disadvantages in foreign languages study, they can take advantages of corpus to better understand the vocabulary and syntax in specific contexts. Moreover, the corpus promotes the efficiency of language input. In addition, the corpus can be digitized with the help of retrieval software such as Antconc. It provides great convenience for foreign language classes to cultivate inter-disciplinary talents. For example, the vocabulary of professional mechanical course textbooks can contribute to the self-built monolingual corpus, and the specialized vocabulary in the vocabulary can be interspersed with basic German teaching to help Students familiarize themselves with mechanical professional vocabulary in advance, and through searching on and summarizing mechanical German text characteristics, it could prepare students for their understanding of German language in professional courses. 


\section{The application of corpus in teaching}

\subsection{Changes in teaching methods}

Krashen believed that understandable input is a necessary condition for language acquisition. He pointed out that the input language information must be real, because language communication activities can only embody and reflect meanings in a real context. The corpus conforms with this characteristic, and it is one of the most important tools in the process of changing teaching methods.

Traditional teaching methods: 1. teacher teaching; 2. student reception; 3. student transformation; 4. teacher evaluation

Teaching methods with corpus: 1 . student retrieval; 2. student to student discussion; 3 . teacher guidance; 4. teacher to student communication; 5 . student to student evaluation; 6 . teacher summary.

Compared these two teaching methods above, traditional teaching methods pay more attention to results, whereas corpus-based teaching methods attach more importance to process. Students turn out more actively to grasp the contextual meaning of vocabulary and structure under corpus-based teaching methods than traditional teaching methods. On the other side, teachers under the lead of corpus-based teaching methods, should behave like a scaffolding, laying out fundamentals and structures of knowledge and methodology to guide students. Once students are able to use the scaffolding to solve problems, achieving learning goals is not hard at all.

In the following part, differentiation of synonyms will be used as an example to show the transformation of teaching methods. Firstly, students are separated into two groups. One group uses the Langenscheidt German Dictionary as a tool, and the other group uses the DWDS corpus electronic dictionary as a tool. The synonyms annehmen and akzeptieren are required to be searched before class and the search results are discussed in groups in advance. Finally, preview results are formed for in-class discussion. The following table shows two sets of search results:

\begin{tabular}{|c|c|c|}
\hline Tools & Langenscheidt Großwörterbuch & DWDS \\
\hline Meaning of Words & $\begin{array}{l}\text { annehmen: } \\
\text { 1. etw., dass j-d einem geben od. Schenken will, nicht } \\
\text { zurückweisen. 2. etw., z.B. ein Angebot, das j-d gemacht } \\
\text { hat, akzeptieren od. mit etw. einverstanden sein. 3. etw. } \\
\text { nachdem man es geprüft hat, akzeptieren od. gut finden } \\
\text { akzeptieren: } \\
\text { 1. mit etw. Einverstanden sein 2. etw. als gegeben } \\
\text { hinnehmen (weil man es nicht ändern kann) 3. etw. gelten } \\
\text { lassen 4. mit j-m einverstanden sein }\end{array}$ & $\begin{array}{l}\text { annehmen: } \\
\text { 1. etw. Angebotenes entgegennehmen } \\
\text { 2. jmdn. aufnehmen } \\
\text { 3. etw. übernehmen } \\
\text { akzeptieren: etw. annehmen }\end{array}$ \\
\hline Collocations & $\begin{array}{l}\text { annehmen: Geschenk, } \\
\text { Einladung, Vorschlag, } \\
\text { Bedingung, Angebot, } \\
\text { Antrag, Gesetzesentwurf } \\
\text { akzeptieren: } \\
\text { Angebot, Vorschlag, Bedingung,Krankheit, Schicksal }\end{array}$ & 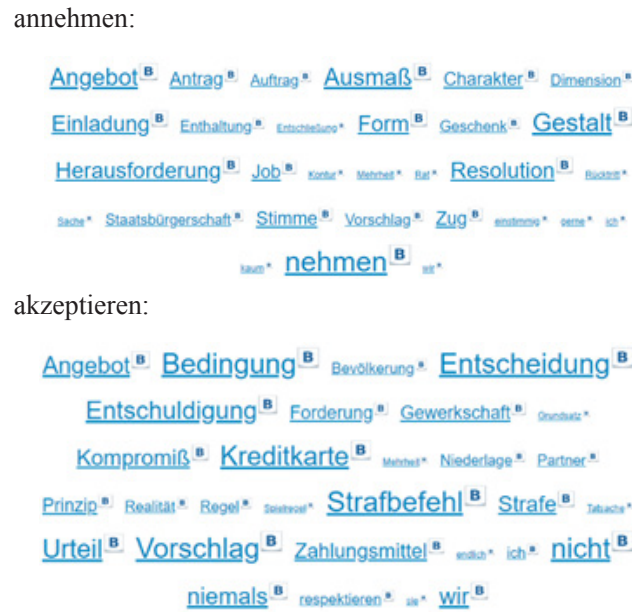 \\
\hline
\end{tabular}

Presentation styles of collocations in the table are quite different, and the results displayed by word cloud and data statistics in corpus dictionaries are more intuitive. Moreover, example words and sentences retrieved in DWDS are all from the corpus of real language materials, which reflect the usage of the words by native speakers, making the teaching content more real and effective. In addition, DWDS also provides a comparison function for the collocation of two sets of synonyms. Students can obtain the data in Figure 1 through operations. 


\section{Suche im DWDS-Wortprofil}

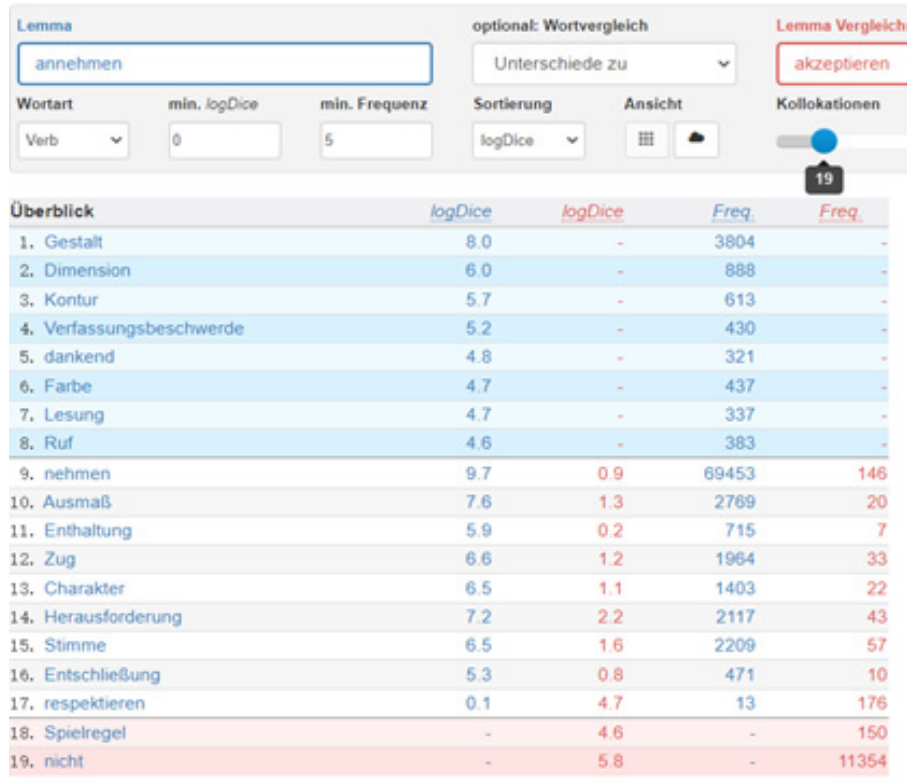

Figure 1. Comparison results of the collocations of annehmen and akzeptieren

Students analyzed the data on the differences between the two words logDice and Freq and got the following results (see Figure 1):

1. Both annehmen and akzeptieren are inclined to collocate with nouns.

2. From the $\log$ Dice indicator, the results in the blue area show that some words only match annehmen, such as Gestalt, Dimension, Kontur, etc., instead of akzeptieren.

3. Comparing the co-matched vocabulary, the results in the white-gray area (based on the logDice value) show that Ausmaß/ Herausforderung/ Stimme/ Entschließung matches annehmen, and less matches akzeptieren.

4. From the logDice indicator, akzeptieren is used with words such as Spielregel/nicht instead of annehmen.

In summary, akzeptieren intends to be used with negative words rather than Annehmen. Annehmen is often affirmative, meaning to accept. Users can also click on a word to view example sentences (see Figure 2) in the process of comparison. The example sentences are provided by a large corpus. There are many types of corpora in the electronic dictionary of DWDS corpus, such as: DWDS-Kernkorpus 21 (2000-2010), Historische Korpora (1465-1969), Berliner Zeitung (19942005), Die Zeit (1946-2018), etc.

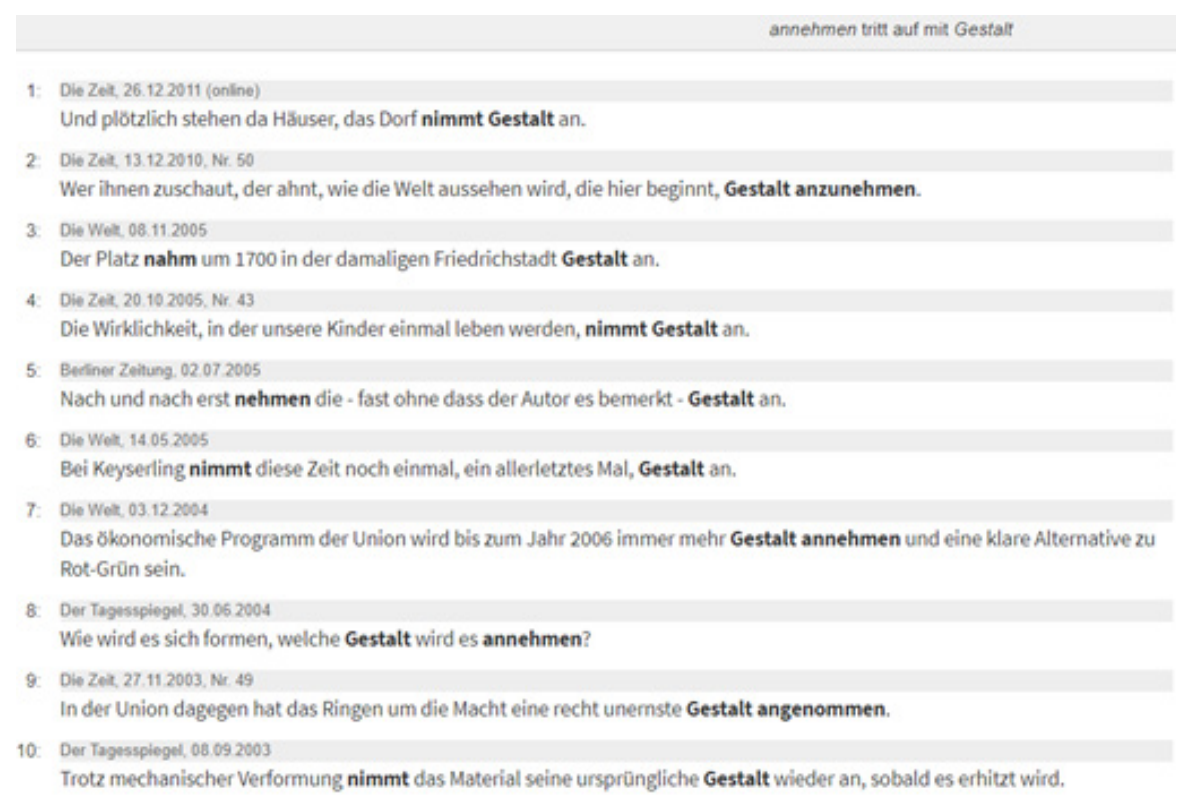

Figure 2. Example sentences with annehmen and Gestalt 
Students have a clearer and deeper understanding of synonyms through their individual exploration of the corpus and comparison of word meanings. Finally, teachers will guide and conclude, and if there are errors, the teacher will point them out. From indoctrination-reciting to exploration-summarization, this change in teaching methods directly improves students' enthusiasm and efficiency in learning.

\subsection{Changes in teaching contents}

As students in the Sino-German joint project start German professional courses in the sophomore year, a higher standard of language proficiency is required. In response, the teaching contents change. Specifically, the learning of mechanical vocabulary and syntax will be added in the first three semesters. Learning is not separated, but in the process of basic German learning, interspersed with mechanical vocabulary and emphasizes the characteristics of mechanical German syntax. This content is based on a self-built mechanical professional monolingual corpus. The corpus contains the vocabulary of the textbooks of this project, which is targeted and can effectively help students adapt to German professional courses in advance.

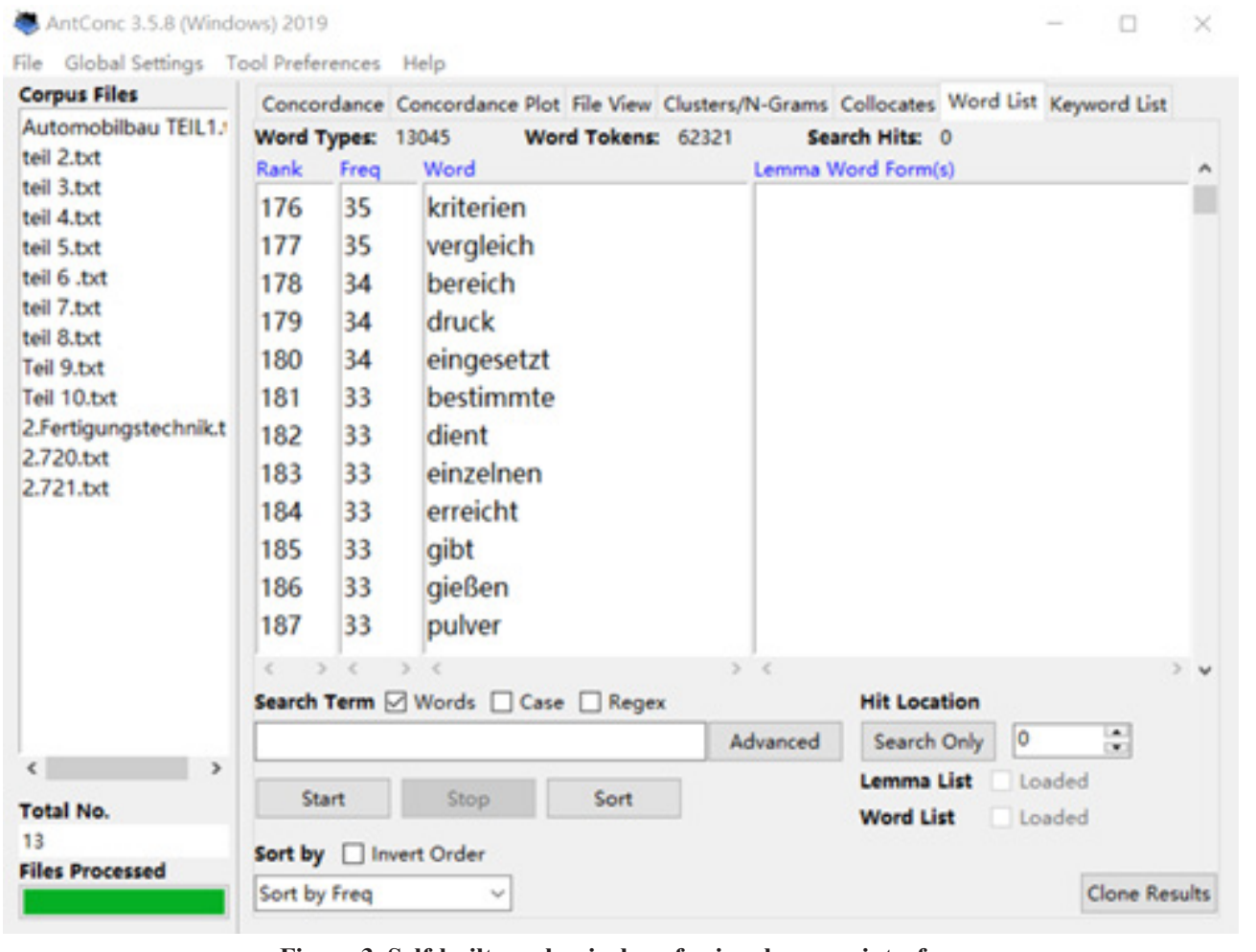

Figure 3. Self-built mechanical professional corpus interface

As shown in the figure above, the self-built corpus based on textbooks has a small storage capacity (Token: 62321) but is very representative for the project and meets the reform requirements of the German course of this project. In the early stage, the teacher screens the vocabulary. The vocabulary made by Antconc was used in the classroom to learn the common meaning of the vocabulary and the mechanical meaning of the vocabulary at the same time.

\section{Conclusion}

The method of integrating corpus into foreign language teaching is not new but has its particularity because this project involves the Sino-German cooperation enducation.

This paper explains methods to integrate the corpus into the German teaching of Chinese-foreign cooperative education majors, to stimulate students' initiative and improve students' ability of self-study or discuss problems with each other. Besides, integrating mechanical professional contents in foreign language teaching is also discussed here. However, the integration of corpus tools in teaching has its shortcomings, such as taking more time of teachers and students to retrieve, analyze and summarize. The proficient use of software is also a challenge. Finally, it takes more steps to integrate the corpus into the curriculum system systematically and completely. 


\section{References}

[1] Lu Feifeng. Research on the Application of the Scaffolding Instruction Model of College German Vocabulary based on Corpus[J]. Journal of Shanghai Polytechnic University, Jun. 2021, Vol. 38 No. 2.

[2] Liang Maocheng. Mini-text and Its Application in Foreign Language Teaching[J]. Technology Enhanced Foreign Language Education, May. 2009, No. 127.

[3] Liang Maocheng, Li Wenzhong, Xu Jiajin. Using Corpora: A Practical Coursebook[M]. Beijing: Foreign Language Teaching and Research Press. 2010.

[4] Huo Yingnan. The Application of Corpus in the Teaching of German[C]. Northeast Asia Forum on Foreign Languages, 48-53.

[5] Sinclair, J. M. Reading concordances: an introduction[M]. Harlow: Longman, 2003. 